\title{
Recurrent High Grade B-Cell Lymphoma with MYC and BCL2 or BCL6 Rearrangements
}

National Cancer Institute

\section{Source}

National Cancer Institute. Recurrent High Grade B-Cell Lymphoma with MYC and BCL2 or

BCL6 Rearrangements. NCI Thesaurus. Code C151980.

The reemergence of high grade B-cell lymphoma with MYC and BCL2 or BCL6

rearrangements after a period of remission. 